\title{
OPEN Mapping coral calcification strategies from in situ boron isotope and trace element measurements of the tropical coral Siderastrea siderea
}

\author{
T. B. Chalk ${ }^{1 凶}$, C. D. Standish ${ }^{1}$, C. D’Angelo ${ }^{1}$, K. D. Castillo ${ }^{2}$, J. A. Milton ${ }^{1}$ \& G. L. Foster ${ }^{1}$
}

Boron isotopic and elemental analysis of coral aragonite can give important insights into the calcification strategies employed in coral skeletal construction. Traditional methods of analysis have limited spatial (and thus temporal) resolution, hindering attempts to unravel skeletal heterogeneity. Laser ablation mass spectrometry allows a much more refined view, and here we employ these techniques to explore boron isotope and co-varying elemental ratios in the tropical coral Siderastrea siderea. We generate two-dimensional maps of the carbonate parameters within the calcification medium that deposited the skeleton, which reveal large heterogeneities in carbonate chemistry across the macro-structure of a coral polyp. These differences have the potential to bias proxy interpretations, and indicate that different processes facilitated precipitation of different parts of the coral skeleton: the low-density columella being precipitated from a fluid with a carbonate composition closer to seawater, compared to the high-density inter-polyp walls where aragonite saturation was $\sim 5$ times that of external seawater. Therefore, the skeleton does not precipitate from a spatially homogeneous fluid and its different parts may thus have varying sensitivity to environmental stress. This offers new insights into the mechanisms behind the response of the $S$. siderea skeletal phenotype to ocean acidification.

Tropical coral reefs are some of the most important ecosystems on the planet, contributing greater than US $\$ 30$ billion in ecosystem services each year worldwide ${ }^{1}$. They are diversity hotspots, offer coastal protection, and sustain important economic activities such as fisheries and tourism. All these ecosystem functions depend on the framework of the reef that is constructed in the extracellular calcifying medium (ECM) - a (sub-)micron-sized space sandwiched between each coral animal and its existing skeleton ${ }^{2}$. Tropical coral reefs and the ecosystems and industries they support face a number of threats from human activity, including rising ocean temperatures, ocean acidification, eutrophication, overfishing, sea level rise, and pollution. These anthropogenic stressors affect key physiological processes in reef-building Scleractinian (stony) corals, such as coral biomineralisation, which in turn impacts aspects of their skeleton (such as rate of extension, density, porosity and strength) leading to decreased fitness ${ }^{3}$, increased coral mortality and ultimately loss of ecosystem functionality.

Calcification within the ECM occurs from semi-isolated pools of modified seawater and the coral animal has tight control on both the carbonate system and crystal growth in this space through the deployment of enzymatic pumps (e.g. Ca-ATPase) and secretion of acid-rich proteins ${ }^{4}$. Tracking the state of the carbonate system in the ECM is emerging as a central methodology underpinning a mechanistic understanding of how environmental change, such as ocean acidification, influences skeletal formation and ultimately the growth of these important ecosystem engineers ${ }^{5-7}$.

Previous attempts to examine ECM composition have primarily used micro-electrodes ${ }^{8}$ or $\mathrm{pH}$ sensitive dyes ${ }^{9}$. While these approaches have revealed many key insights, they are by their nature invasive, requiring either the insertion of needle-like electrodes into the calcification space or the growth of the coral on glass slides to allow direct observation of the ECM with confocal microscopy. Incisions are made to insert the micro-electrodes in

${ }^{1}$ School of Ocean and Earth Science, University of Southampton, National Oceanography Centre Southampton, Southampton, UK. ${ }^{2}$ Marine Sciences, University of North Carolina at Chapel Hill, Chapel Hill, NC, USA. ${ }^{\square}$ email: t.chalk@noc.soton.ac.uk 


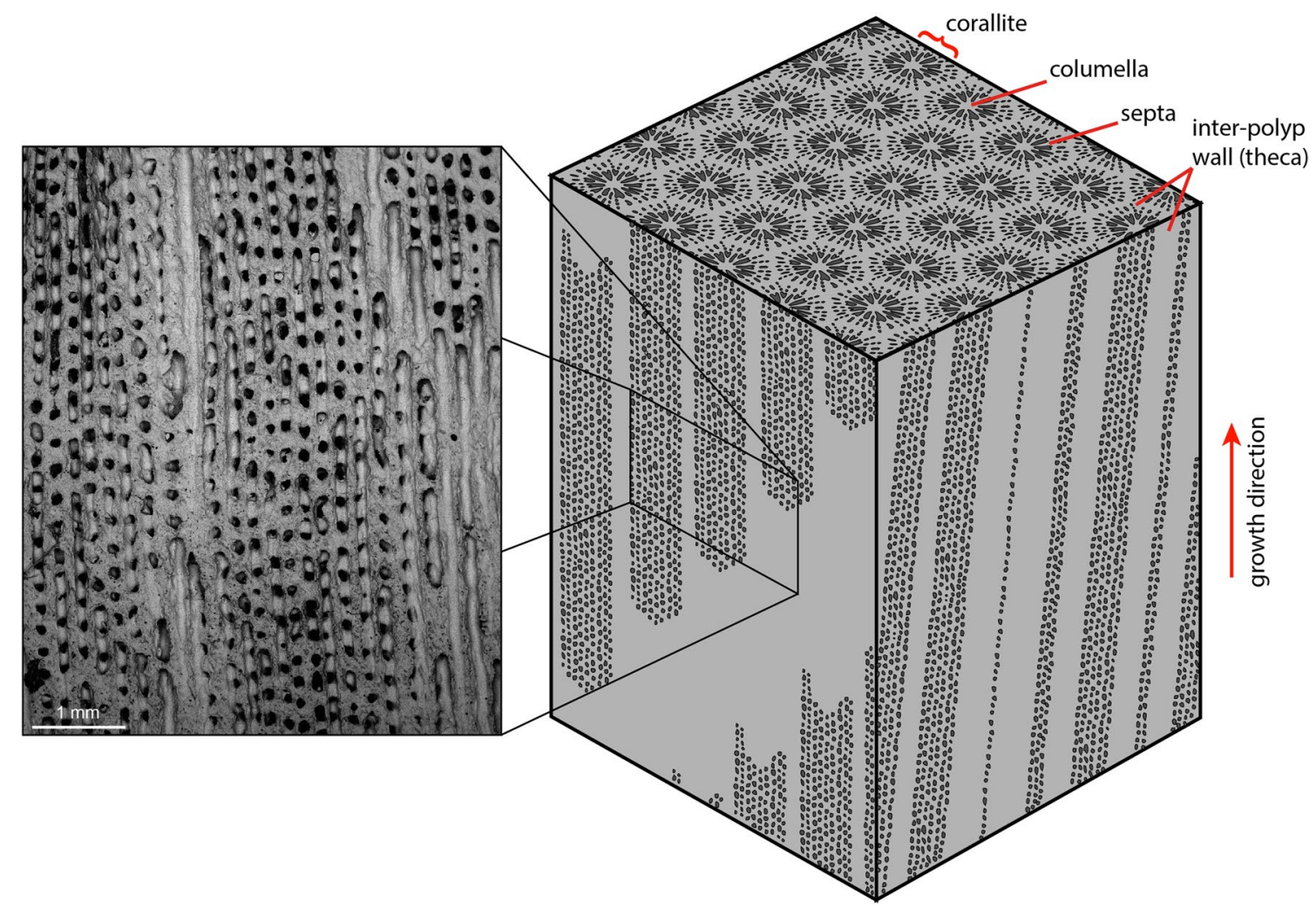

Figure 1. Schematic showing the complex three-dimensional structure of colonial coral skeletal material (in this case Siderastrea siderea). Coral polyps make up quasi-cylindrical structures (stippled) surrounded by denser wall structures (grey). When sectioned skeletal features will dip into and out of the section plane, as they do not grow along a perfectly straight axis in all dimensions, therefore it is imperative that a detailed understanding the skeletal structure measured is known. Mapping a planar surface allows the substructure to be penetrated. The analysed area is shown in the inset.

the coral animal or via its oral orifice, which can adversely affect the organism and likely change the composition of the calcification space ${ }^{10}$, whilst growing the coral on a glass slide may disrupt some coral growth morphology and in turn impact the calcification process. In addition, both methods only provide snapshots of information for corals grown in laboratory conditions. The boron isotopic composition of the skeleton has a proven track record as a sensitive tracer of the $\mathrm{pH}$ of this calcifying fluid $\left(\mathrm{pH}_{\mathrm{cf}}\right)$ at the moment the skeleton is precipitated ${ }^{11}$, and when combined with ECM fluid $\left[\mathrm{CO}_{3}{ }^{2-}\right]$ estimated from $\mathrm{B} / \mathrm{Ca}^{12}$, can further interrogate the nature of the internal carbonate system ${ }^{13}$. This boron-based approach is non-invasive (though it has to be utilised on carbonate which has already been precipitated), and it can also be applied to samples grown in the field under natural conditions and over longer temporal intervals. Furthermore, if sampling resolution is sufficiently controlled, the boron isotope-based methods can more readily provide information regarding the spatial variability of the carbonate system within the ECM in different parts of the coral skeleton. A key example of this is between the porous columella (here used to define the interior of the polyp) and the densely calcified thecal wall (Fig. 1), which appear to respond differently to environmental stress that may underpin the organism-level response to environmental change ${ }^{14,15}$.

Previous boron isotope records of the $\mathrm{pH}_{\mathrm{cf}}$ have typically (but not exclusively ${ }^{16-18}$ ) employed bulk sampling techniques such as micromilling which average across the various structural elements of the coral skeleton. These bulk approaches are restricted by the typical sample requirements of solution boron isotope analysis, i.e. $>0.5 \mathrm{mg}$ of carbonate for a precision of $<0.3 \%$, which makes truly sampling discrete skeletal components in most species extremely challenging. Further complications arise from the geometry of coral growth (Fig. 1) which forms a complex and anastomosing structure often passing through the plane of section. The extent to which these structural components will impact bulk sampling data varies by species, but some degree of component mixing during sampling with bulk approaches is highly likely in most cases, and this will include pre-existing calibration studies which are critical to studies employing the boron isotope- $\mathrm{pH}_{\text {proxy }}{ }^{19-24}$. Secondary Ionisation Mass Spectrometry (SIMS) with a spatial resolution down to $10 \mu \mathrm{m}$, can overcome many of these spatial issues, but at the cost of precision and sample throughput (i.e. analyses are time consuming only allowing the examination of small analysis areas) that can limit the applicability of this technique with current methodologies ${ }^{25-27}$. In species with small-scale structure (e.g. Porities spp.), bulk sampling is perhaps more likely to provide a good mean value as the effective mixing of components will be more likely on the scale of a $0.5-1 \mathrm{~mm}$ drill-bit.

New analytical techniques now allow accurate in situ measurements of $\delta^{11} \mathrm{~B}$ constrained to the fine scale structure of coral skeletons by employing laser ablation MC-ICP-MS ${ }^{28-30}$. Alongside elemental analysis by laser 
ablation ICP-MS ${ }^{31}$, such an approach is able to explore the spatial variation in boron isotopic composition and boron concentration (alongside other key element ratios) across the various skeletal components, ultimately enabling the construction of two-dimensional maps exploring the full carbonate system of the ECM. Here we apply this laser ablation methodology along with well-constrained bulk sampling methods for the first time to a tropical, reef-building, coral Siderastrea siderea, covering an $\sim 18$ month period of growth from $\sim$ June 2006 to January 2008. These analyses allow a reconstruction of the full carbonate system of the ECM from the skeleton at an unprecedented temporal and spatial resolution, permitting an examination of the influence of the carbonate system in the ECM on skeleton construction.

\section{Results}

Solution and laser ablation boron isotope data. Solution and laser ablation (LA) analyses were carried out on coeval polyps of the same colony of Siderastrea siderea (Fig. 2) in order to verify the accuracy of the laser ablation approach followed. Samples of the finest possible resolution were micromilled $(\sim 500 \mu \mathrm{m}$ diameter $=0.2-0.5 \mathrm{mg}$ ) and analysed by solution, and these were compared to 30 linear transects covering an approximately equal area measured by LA. For further details see "Materials and methods" section.

The solution data (supplementary data 1 ) show a relatively smooth annual cycle of $\delta^{11} \mathrm{~B}$ of $\sim 2 \pm 0.9 \%$ (2SD) ranging from 21.5 to $24.5 \%$ (red and blue boxes in centre plot and circles in right side SEM image, Fig. 2a). The columella dominated samples show a more muted annual cycle (22.5-24\%; blue shaded boxes and circles, Fig. 2) than the wall dominated samples which span the full range of variability (red boxes and circles). These data clearly highlight the importance of skeletal component in determining $\delta^{11} \mathrm{~B}$, given that there is $>1 \%$ o difference in $\delta^{11} \mathrm{~B}$ between the macro-structural elements of the polyp across a given temporal horizon (Fig. 2), here assumed to be approximately perpendicular to the growth axis.

To facilitate a better comparison to the solution data, the LA data in Fig. 2 were smoothed with a 40-point moving window (supplementary data 2). This treatment also reveals a broad annual cycle in all the tracks analysed, albeit with a slightly higher variance in comparison to the solution data $(19.2-26.6 \%$; 5 th and 95 th percentiles for laser data, compared to $21.5-24.5 \%$ for solution data; Fig. 2), which is to be expected considering the higher initial resolution and the different resolution in the z-direction $(\sim 5 \mu \mathrm{m}$ vs. $\sim 500 \mu \mathrm{m}$ for the LA and solution data respectively). The average amplitude from peak to trough along each individual track is $3.4 \pm 1.2 \%$ (2SD, Figures S1 and S2), which is similar to the solution data, but there is no significant deviation from this amplitude between skeletal components. However, the average values of the tracks themselves varies from 21.2 to $24.5 \%$, a difference of $3.3 \%$ (Figure S1). There is a strong visual correlation between the mean of each track and the structural component analysed, with higher $\delta^{11} \mathrm{~B}$ associated with components of the denser theca walls relative to the more porous internal parts of the polyp and columella (Fig. 2). We note that allocation of the ablated area to theca walls and columella is complicated by the structure beneath the plane of section that is visible on the SEM image, and that this may explain the highest $\delta^{11} \mathrm{~B}$ in the columella closest to the visible walls (e.g. Fig. 1). An overall trend to decreased $\delta^{11} \mathrm{~B}$ values of $\sim 1 \%$ o per year is visible across the analysed section for both analytical methods (i.e. lower $\delta^{11} \mathrm{~B}$ towards the top of the coral piece). These data are also consistent with the low resolution annually averaged measurements of Fowell et al. ${ }^{32}$ from the same coral in terms of both the mean values and the apparent multiannual trend towards lower $\delta^{11} \mathrm{~B}$ values from 2006 to 2008 .

Over coeval horizons the LA and solution datasets show overlapping values and cyclicity (Fig. 2) that are consistent with previous comparisons ${ }^{28}$. This indicates that the two methodologies, as well as the $\delta^{11} \mathrm{~B}$-systematics in the two individual polyps from the colony analysed, are consistent. Indeed, the average of the solution data is $22.92 \pm 1.58 \%$, compared to the laser average of $22.93 \pm 3.29 \%$ o (both at $2 \mathrm{SD}$ ), with the increased variance of the LA data likely due to the capturing of finer scale details. Overall, the agreement between the two analytical methods is very good, which adds confidence to the utility of in situ LA as a means to improve our understanding of coral microstructure at a spatial scale unachievable by micromilling and solution based methods.

Spatial patterns from mapping of $\delta^{11} \mathrm{~B}$ and elemental ratios. Given a knowledge of the $\mathrm{X}$ and Y locations, the unsmoothed LA data can be used to produce high resolution 2D maps of the analysed specimen (Fig. 3; see "Materials and methods" section), which in this instance provides an unparalleled insight into the nature of the relationship between coral macro-structure and the calcification processes. The higher spatial resolution enables a better measurement of the true variance of the $\delta^{11} \mathrm{~B}$ within the skeleton, allowing the seasonal (and sub-seasonal) changes to be fully resolved rather than aliased by lower sampling resolution (e.g. unsmoothed the LA data shows a 7.4\%o 95 th-5th percentile range compared with $2.9 \%$, for solution). In the $2 \mathrm{D} \delta^{11} \mathrm{~B}$ map shown in Fig. 3, the broad structural variations identified by the solution data, i.e. higher $\delta^{11} \mathrm{~B}$ in the theca walls relative to the columella, are clearly illustrated. Moreover, the structure can be further refined within these two major structural divisions to identify small-scale features within the columella and theca walls. For instance, within the LA $\delta^{11} \mathrm{~B}$ maps (Fig. 3) a small scale periodicity to the $\delta^{11} \mathrm{~B}$ can also be seen, perhaps most easily at the interface of the wall and columella (see Fig. $3 \mathrm{~b}$ ). These variations are only $\sim 1 \%$ which is small relative to the analytical uncertainty (typically $\sim 0.6 \%$ 2SD based on the external reproducibility of the in-house coral reference material PS69/318-1) and we thus limit our interpretation of these features. They do, however, appear to have an occurrence frequency of 10-12 per year close to the lunar month frequency and therefore may be related to monthly aragonite dissepiment formation ${ }^{33-35}$.

The co-located 2D maps of skeletal trace element composition show that the theca walls of the polyps analysed have elevated $\delta^{11} \mathrm{~B}, \mathrm{~B} / \mathrm{Ca}, \mathrm{Mg} / \mathrm{Ca}, \mathrm{Sr} / \mathrm{Ca}, \mathrm{Ba} / \mathrm{Ca}$ relative to the centre of the polyp, and are depleted in $\mathrm{U} /$ $\mathrm{Ca}$ (Figs. 3 and 4). Like $\delta^{11} \mathrm{~B}$, many of the trace element ratios also show a seasonal cycle (i.e. 1.5 cycles over the 18 months of growth analysed). For $\delta^{11} \mathrm{~B}, \mathrm{Mg} / \mathrm{Ca}$ and $\mathrm{U} / \mathrm{Ca}$ the average change across the coral components (x-direction) is larger than that found along the growth axis (y-direction, see Table S3). In B/Ca, Sr/Ca and Ba/Ca 

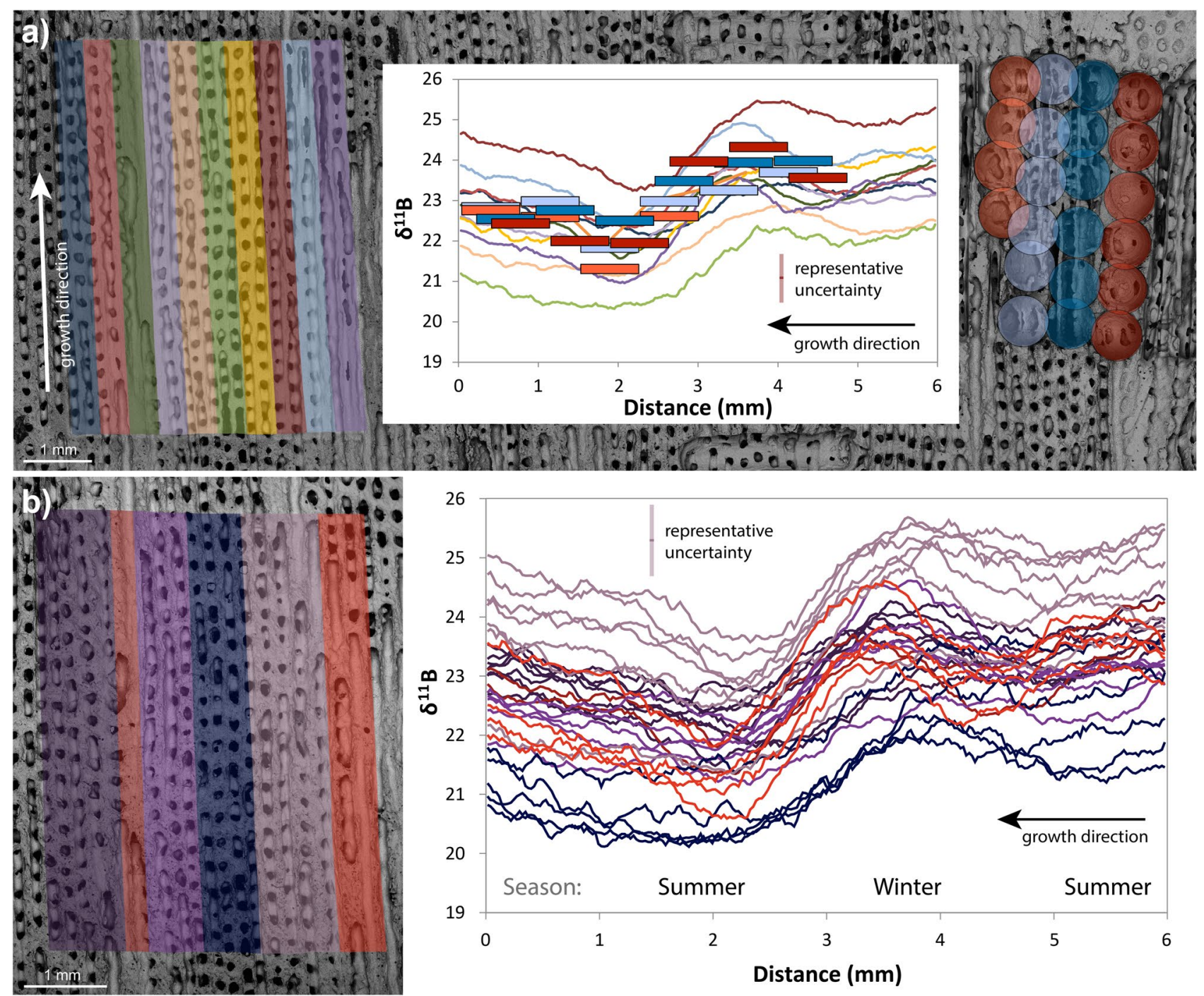

Figure 2. (a) SEM image of coral with: (left) traces of LA tracks grouped into sets of three $(\sim 450 \mu \mathrm{m}$ wide from $150 \mu \mathrm{m}$ width rasters), and (right) micro drilled sampling holes for solution analysis (500 $\mu \mathrm{m}$ width drill-bit) where red shows samples predominantly centred on the theca wall and the blue shows samples predominantly located within the columella of the polyp, where the radial septa join. The central plot shows corresponding $\delta^{11} \mathrm{~B}$ data from LA (40-point running average) and solution methods. Solution boxes are sized to show $2 \sigma$ uncertainties as box height and drill bit size as X-axis length, and data for both solution and LA are plotted as per the colours on the SEM image. Solution and laser data agree well within the different structural components, with the LA data showing higher variance as expected from the larger area and finer detail captured. The left side of the plot is the bottom of the SEM image, and the right side is the top. (b) Laser ablated transects (right, 40-point running averages) of $\delta^{11} \mathrm{~B}$ from different skeletal elements (left) of same area of coral. Red colours indicate transects visually identified as predominantly theca wall, these show a clear and sharp annual cycle. Dark blue indicates the area around the columella, which shows a muted annual cycle and a lower average value. Purple colours indicate mixed transects where both distal columella, septa and theca wall edges are measured. Note: the seasonal cycle is visible in each group and in the solution data and does not vary widely in amplitude (see Figure S1). X-axis as above, representative uncertainty for LA data is shown in both plots.

however, temporal/environmental variability dominates over structural differences (see Table S1). This finding cautions the use of poorly resolved or bulk sampling strategies as a way to recover environmental data from coral aragonite, as this approach risks being unduly impacted by variability relating to coral macro-structure. This will be of particular importance in coral with large-scale macro-structure like Siderastrea siderea.

In this study, we concentrate on the internal carbonate system as revealed by a combination of $\delta^{11} \mathrm{~B}$ and $\mathrm{B} /$ $\mathrm{Ca}$ (see below), but we note that variations in some elements are clearly strongly related to variability in the carbonate system of the ECM. For instance, bulk sampling has revealed a negative relationship between coral $\mathrm{U} / \mathrm{Ca}$ and $\mathrm{pH}^{36}$ and this is also replicated here between the wall and columella of a single polyp (e.g. comparing Fig. 4 f with Fig. 5a). 

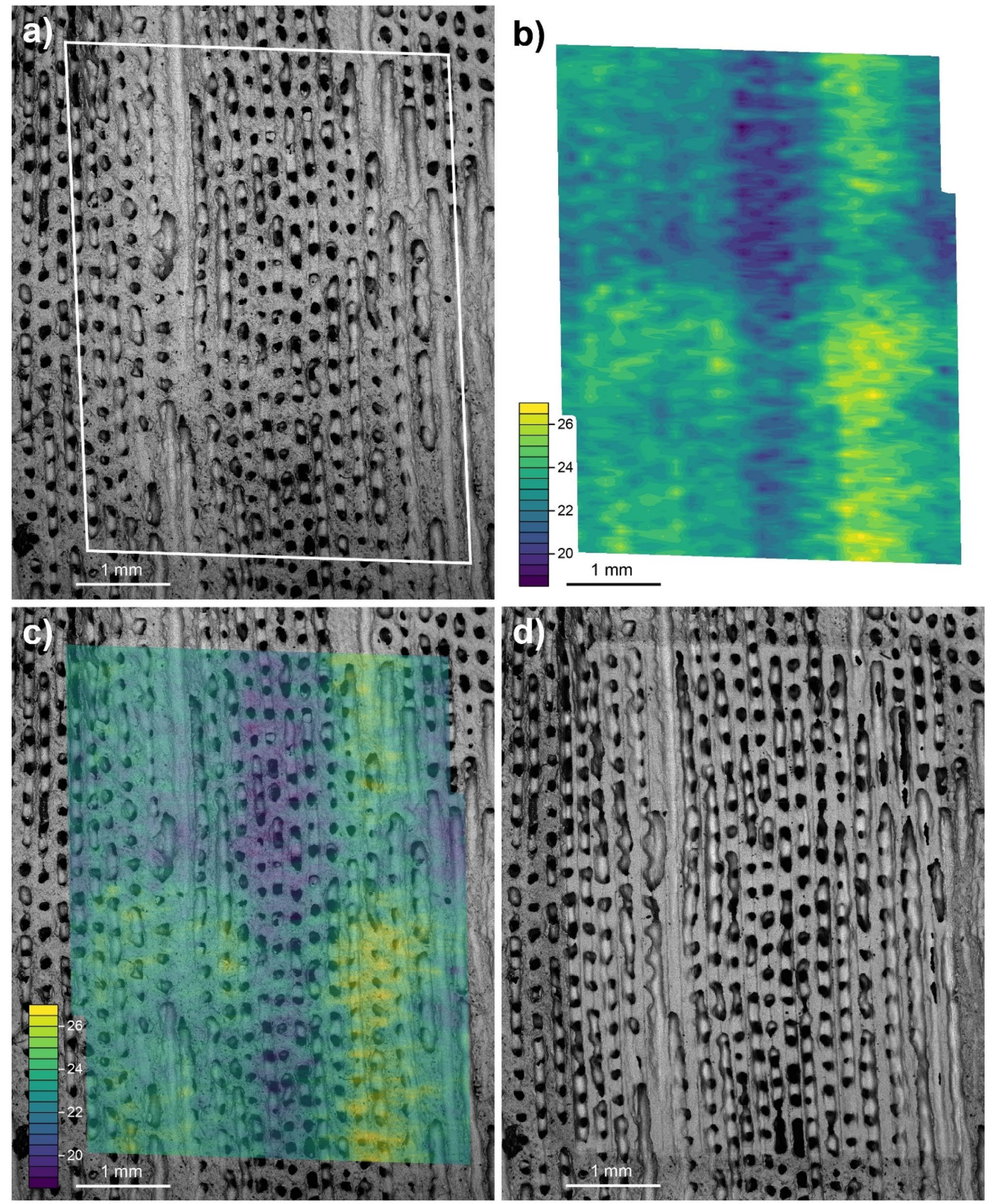

Figure 3. (a) Pre-ablation SEM image of the coral sector analysed by LA; (b) $\delta^{11} \mathrm{~B}$ map of coral area, where yellow colours show high $\delta^{11} \mathrm{~B}$ values $\left(>25 \%\right.$ ), green colours show intermediary $\delta^{11} \mathrm{~B}$ values (c.21-25\%o) and blue colours show low $\delta^{11} \mathrm{~B}$ values $\left(<21 \%\right.$ ); (c) Overlay of $\delta^{11} \mathrm{~B}$ map and SEM image, the values clearly match the structural elements of the coral with high values being confined to the polyp walls and low values to the columella. Sub-annual variability of $\sim 1 \%$ is visible in the wall edges which may correspond to the dissepiments (not-visible). The two walls analysed show very similar trends but at different absolute values implying a potential 3-dimensional component to the analyses. (d) Post-ablation SEM image of the coral area ablated. 

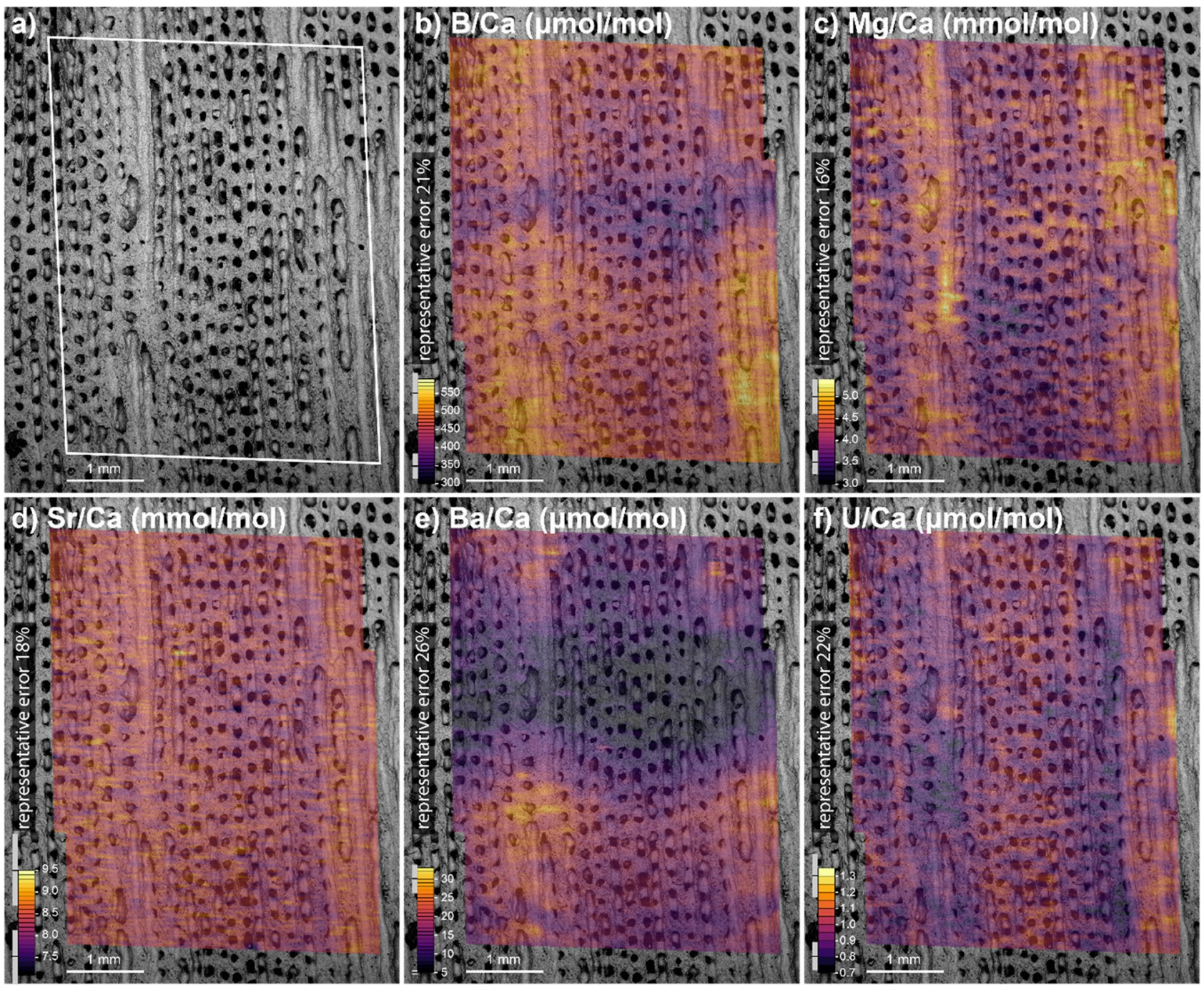

Figure 4. (a) Pre-ablation SEM image of the coral area analysed by LA, note the element ratio plots were analysed prior to the $\delta^{11} \mathrm{~B}$ analyses as they utilise less material. The following plots are mapped onto the SEM image with high values shown in yellow colours and low values in purple: (b) $\mathrm{B} / \mathrm{Ca}$ in $\mu \mathrm{mol} / \mathrm{mol} \mathrm{ranging}$ from $<350$ to $>550 \mu \mathrm{mol} / \mathrm{mol}, \mathrm{B} / \mathrm{Ca}$ has a strong seasonal variation associated with changes to the internal carbonate system of the coral; (c) $\mathrm{Mg} / \mathrm{Ca}$ in $\mathrm{mmol} / \mathrm{mol} \mathrm{ranging}$ from $<3.5$ to $>5.0 \mathrm{mmol} / \mathrm{mol}$; (d) Sr/Ca in $\mathrm{mmol} / \mathrm{mol}$ ranging from $<8.0$ to $>9.0 \mathrm{mmol} / \mathrm{mol}$; (e) Ba/Ca in $\mu \mathrm{mol} / \mathrm{mol}$ ranging from $<10$ to $>30 \mu \mathrm{mol} /$ $\mathrm{mol}$, the $\mathrm{Ba} / \mathrm{Ca}$ shows a strong seasonal cycle associated with riverine input, we note the visible undulation to the growth horizon as also seen in the $\mathrm{B} / \mathrm{Ca}$ data showing the gross morphology of a coral polyp with raised theca walls and a depressed central polyp at any given time-step; (f) $\mathrm{U} / \mathrm{Ca}$ in $\mu \mathrm{mol} / \mathrm{mol}$ ranging from $<0.8$ to $>1.1 \mu \mathrm{mol} / \mathrm{mol}$. All trace and major element cations are higher concentration in the theca walls, with the exception of uranium (panel f). Uncertainties in the element ratios are shown as representative error bars at the top and bottom of the colour bars, for further information see Laser Ablation ICP-MS section in the methods.

Coral calcification. Figure 5 shows $2 \mathrm{D}$ maps of the carbonate system variables $\mathrm{pH},\left[\mathrm{CO}_{3}{ }^{2-}\right]$, aragonite saturation state in the calcifying fluid $\left(\Omega_{\mathrm{cf}}\right)$, and $\left[\mathrm{HCO}_{3}{ }^{-}\right]$calculated following established methodologies ${ }^{12,13}$ from $\delta^{11} \mathrm{~B}$ and $\mathrm{B} / \mathrm{Ca}$ data (as well as calcium, temperature, salinity and pressure, which are kept invariant for this study as their impact on the calculations is minor, see "Materials and methods" section for details). The calculated carbonate system parameters indicated $\mathrm{pH}, \Omega_{\mathrm{cf}}$, and carbonate ion $\left(\left[\mathrm{CO}_{3}{ }^{2-}\right]\right)$ were higher in the ECM that deposited the theca walls, while $\left[\mathrm{HCO}_{3}^{-}\right]$and thus DIC (as $\left[\mathrm{HCO}_{3}^{-}\right]$dominates DIC at these $\mathrm{pH}$ values) were higher in the columella. There is an annual cycle in all structural elements, where the minimum $\mathrm{pH}$ in the theca walls (summer) is similar to the maximum in the columella (winter), this may be related to the difference in seasonal skeletal density. Centres of calcification (COC) may account for some of the higher variability resolved in the LA data, however, they are likely to be smaller than our spatial resolution $(\sim 10 \mu \mathrm{m})$ suggesting their role in generating the patterns we observe here is minor. However, we note that COC can be characterised by low $\delta^{11} \mathrm{~B}$ and $\mathrm{U} /$ $\mathrm{Ca}$, and high $\mathrm{Mg} / \mathrm{Ca}^{16,37,38}$, which is not consistent with the larger spatial pattern observed here (e.g. columella with low $\delta^{11} \mathrm{~B}$ and $\mathrm{Mg} / \mathrm{Ca}$, and high $\left.\mathrm{U} / \mathrm{Ca}\right)$. 


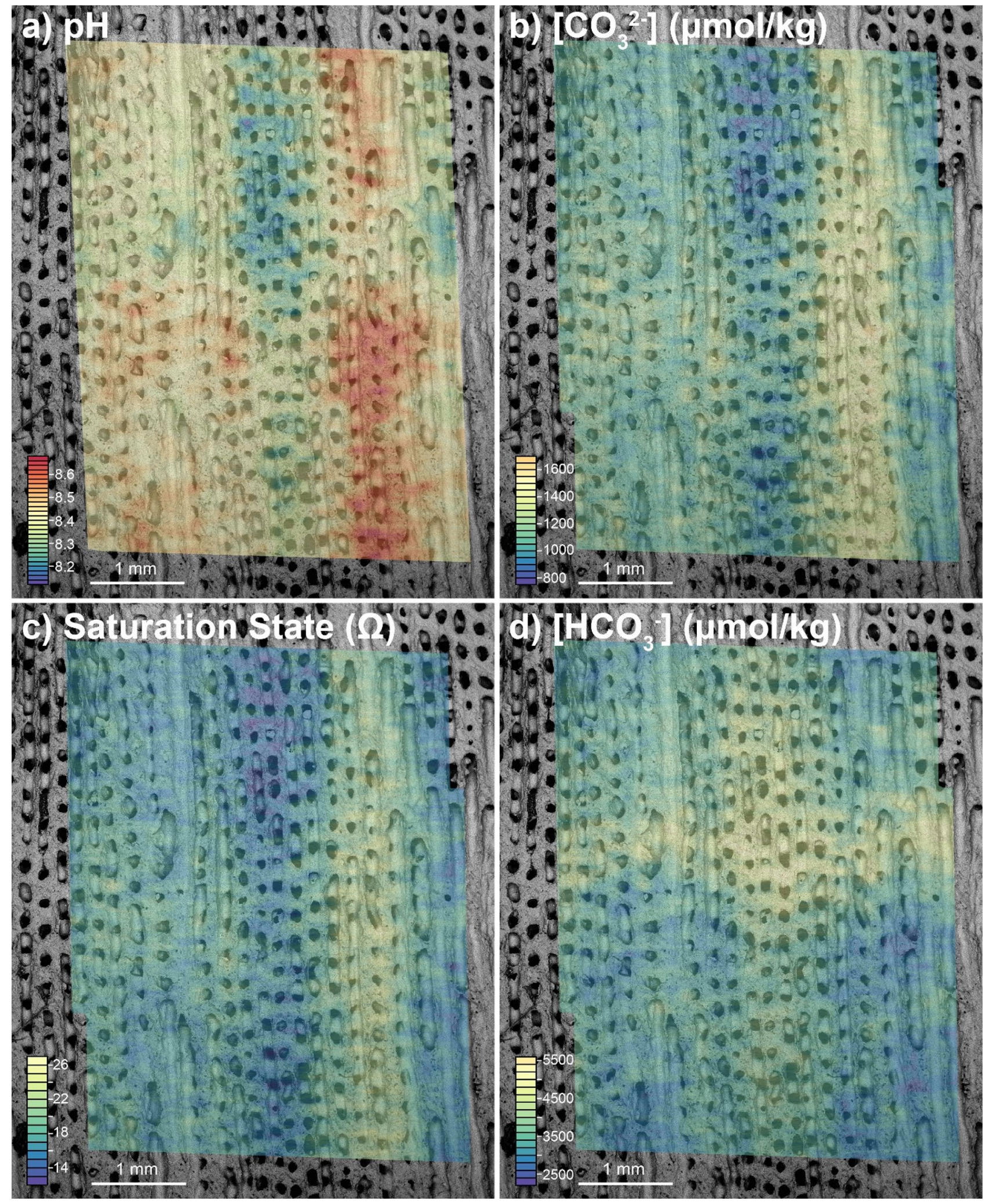

Figure 5. Four plots showing carbonate system parameters recovered from the calcifying fluid: (a) $\mathrm{pH}_{\mathrm{cf}}$ calculated from $\delta^{11} \mathrm{~B}$, as is clear from the raw data the $\mathrm{pH}$ is elevated in the wall compared to the columella, though both show an annual cycle and sub-annual features are visible within the walls; (b) carbonate ion $\left[\mathrm{CO}_{3}{ }^{2-}\right]_{\mathrm{cf}}$ calculated from $\delta^{11} \mathrm{~B}$ and $\mathrm{B} / \mathrm{Ca}$, similar to $\mathrm{pH}_{\mathrm{cf}}$, carbonate ion is elevated in the walls and shows an annual cycle; (c) aragonite saturation state calculated using $\delta^{11} \mathrm{~B}$ and $\mathrm{B} / \mathrm{Ca}$ data, as expected from $\mathrm{pH}_{\mathrm{cf}}$ and $\left[\mathrm{CO}_{3}{ }^{2-}\right]_{\mathrm{cf}}$ the saturation state is higher in the denser material of the walls, and tending towards seawater values at the centre of calcification; (d) bicarbonate $\left(\mu \mathrm{mol} / \mathrm{kg}\right.$ ) calculated from $\delta^{11} \mathrm{~B}$ and $\mathrm{B} / \mathrm{Ca}$. For further details see "Materials and methods" section. 


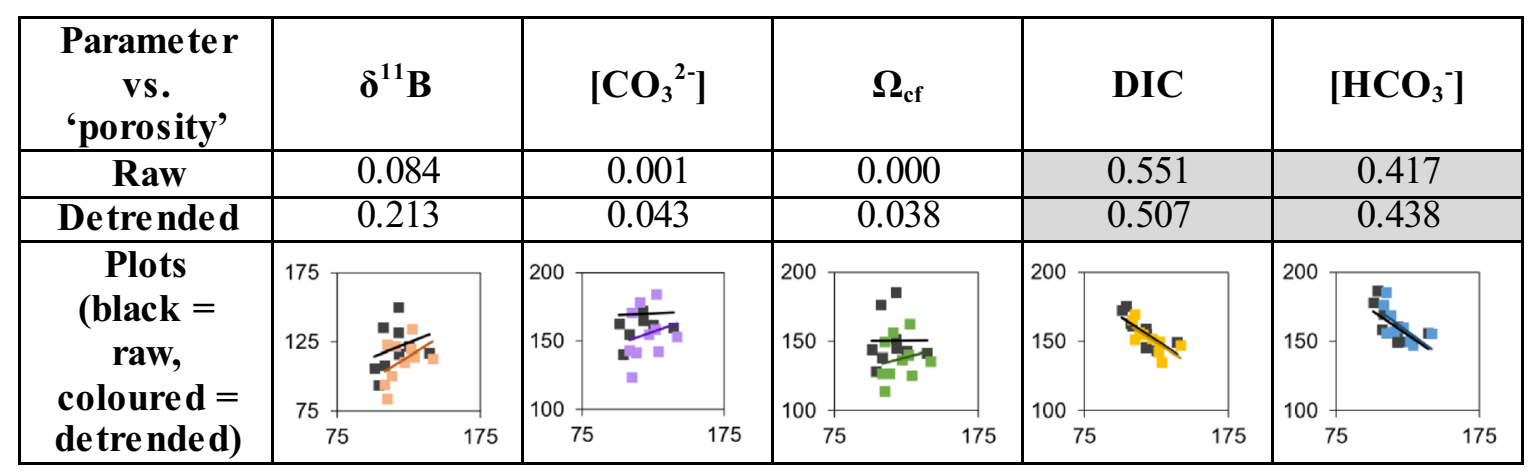

Table 1. Correlation coefficient squared $\left(\mathrm{r}^{2}\right)$ between 'grey-scale value', here a proxy for porosity, $\delta^{11} \mathrm{~B}$, and the reconstructed carbonate system variables as raw data and with linear trends removed. The strongest relationships are with $\mathrm{DIC}$ and $\left[\mathrm{HCO}_{3}{ }^{-}\right]$(and are negative), both in raw and detrended datasets. In the third row of the table are cross-plots with the 'grey-scale value' on the $\mathrm{x}$-axis versus the carbonate system parameter on the y-axis. Black squares are raw data and coloured squares are detrended. For further details, see figure S2. The values in grey boxes indicate where the relationship is statistically significant $(p<0.05)$.

To further investigate the association of elemental and isotopic distribution with structure we compare greyscale values of the SEM image with similarly processed images of the LA-derived ECM carbonate system data (See "Imaging comparison to porosity", Figure S2). As pores are characterised by darker greyscale values relative to densely mineralised areas, this acts as a qualitative link between macro-structure/skeletal density and ECM composition. With this treatment we find a weak relationship between $\delta^{11} \mathrm{~B}$ and porosity $\left(\mathrm{r}^{2}=0.21, p\right.$ value $\left.=0.18\right)$, confirming the visual relationship evident in Fig. 3 (albeit only significant at the $\sim 80 \%$ level of confidence). Table 1 summarises the relationship between porosity and all the calculated carbonate system parameters. There is clearly a strong covariance between skeletal density and ECM composition, with the strongest and only statistically significant being the negative relationships between skeletal density and both $\left[\mathrm{HCO}_{3}^{-}\right]$and DIC (Figure S3, $r^{2}=0.42$ and 0.55 respectively, $p$ values $=0.04$ and 0.01 respectively; Table 1 ), thought to be the crucial carbonate variables for controlling calcification ${ }^{39-42}$. These correlations imply that the porous columella aragonite is associated with a lower degree of $\mathrm{pH}$-upregulation and higher degree of $\left[\mathrm{HCO}_{3}^{-}\right]$(and thus DIC) elevation in the ECM than involved in the construction of the less porous thecal wall. This may be facilitated either by enhanced activity of bicarbonate anion transporters or increased passive diffusion of $\mathrm{CO}_{2}$ into the $\mathrm{ECM}$ in the columella region relative to the theca walls ${ }^{43-45}$. Importantly, the higher $\mathrm{pH},\left[\mathrm{CO}_{3}{ }^{2-}\right]$ and $\Omega_{\mathrm{cf}}$ in the thecal walls favours stoichiometric aragonite precipitation, required for the denser calcification of this structure.

The most likely explanation for these patterns is that while the coral organism directly modifies the semiisolated seawater reservoirs in the ECM to favour skeletal precipitation, it varies the degree of upregulation between skeletal components. The interior of the polyp is marked by lower $\mathrm{pH}, \Omega_{\mathrm{cf}},\left[\mathrm{CO}_{3}{ }^{2-}\right]$, leaving it closer in composition to that of ambient seawater, but with elevated $\left[\mathrm{HCO}_{3}^{-}\right]$(and DIC) which is actively transported into the $\mathrm{ECM}^{40}$. Potentially the less dense skeleton in the columella region is the product of aragonite precipitation more heavily mediated by organic components, aided by the transport the bicarbonate ion, rather than from elevated $\mathrm{pH}$ as seen in the walls ${ }^{3}$. The difference in $\Omega_{\mathrm{cf}}$ between wall $(>20)$ and columella $(<10)$ is particularly significant as elevated saturation state markedly favours precipitation of new crystals and enables dense growth of the organism in the walls ${ }^{6,9}$ (Fig. 5). These results show that the coral ECM is not a spatially homogenous fluid, but varies between skeletal components which in turn impacts skeletal porosity; denser skeleton is associated with higher $\mathrm{pH}$ and $\left[\mathrm{CO}_{3}{ }^{2-}\right]$ and the more porous columella with elevated DIC and $\left[\mathrm{HCO}_{3}{ }^{-}\right](\sim 2$ times above seawater).

Taken together, these findings show that the calcification process in Siderastrea siderea is highly dependent on which part of the skeleton is being precipitated, meaning that the coral organism potentially has access to a diverse "biomineralisation tool kit" which may lead to different strategies being employed in aragonite precipitation in different parts of the skeleton. This has mechanistic implications for results seen in laboratory experiments where lowered seawater $\mathrm{pH}$ commonly leads to a more porous skeleton ${ }^{3,15}$. Indeed, Horvath et al. ${ }^{14}$ note that in Siderastrea siderea much of the decline in calcification associated with decreasing seawater $\mathrm{pH}$ was the result of less in-filling of the corallite, i.e. that the columella became more porous at low seawater $\mathrm{pH}$. Our results suggest that this behaviour may be the result of either: (i) the lower $\mathrm{pH}_{\mathrm{cf}}$ and $\Omega_{\mathrm{cf}}$ upregulation of the columella region causing calcification in that region to be impacted by declining seawater saturation state to areater extent than the theca wall; and/or (ii) the higher $\mathrm{pH}_{\mathrm{cf}}$ and $\Omega_{\mathrm{cf}}$ seen in the theca walls may result in a greater relative impact of acidification on the carbonate system in the ECM of the thecal wall, reducing wall calcification to a greater extent than columella calcification, decreasing overall density and leading to a particular calyx being made up of more porous columella than dense wall. Regardless, variability in the nature of the tools employed by the coral for skeletal construction appear to dictate the response of the skeletal phenotype at least to this particular environmental stress.

Repercussions for using $\delta^{11} \mathrm{~B}$ to reconstruct past seawater $\mathrm{pH}$ variability. Beyond the implications for biomineralisation, the findings from our detailed mapping of the isotopic and chemical composition 
of the skeleton of Siderastrea siderea has wide-ranging repercussions on sampling for the reconstruction of past environmental variables. We find that theca wall samples, traditionally identified for easy sampling and large signal-to-noise ratios in geochemical studies ${ }^{46}$ are furthest removed from the $\mathrm{pH}$ of ambient ocean water. The central polyp, which has the same amplitude of annual cycle as the theca wall, is characterised by a $\mathrm{pH}_{\mathrm{cf}}$ that is closest to $\mathrm{pH}_{\mathrm{sw}}$. Variable mixing of structural components during sampling therefore has the potential to influence the resulting reconstructed $\mathrm{pH}$ signal, as the variation across the polyp is similar in scale in Siderastrea siderea at least to the $\mathrm{pH}$ variability associated with an annual cycle (Table S1). Further calibration of the $\delta^{11} \mathrm{~B}-\mathrm{pH}$ proxy is needed focusing on these structural elements, and the creation of multipolyp maps such as these are recommended to aid in the interpretation of laser ablation $\delta^{11} \mathrm{~B}$ data in such future studies. Across almost the entire polyp structure, the amplitude of change (peak-to-trough) in an annual cycle is constant, barring the very centre of the polyp, which is also evident in the solution data. This shows that existing $\delta^{11} \mathrm{~B}$-derived $\mathrm{pH}$ records are likely to be correct regardless of component measured, as long as mixing proportions are approximately constant.

\section{Conclusions}

We have shown that using laser ablation mapping techniques it is possible to fully constrain the carbonate system of the internal calcifying fluid of the coral Siderastrea siderea at $<200 \mu \mathrm{m}$ scale or sub-monthly temporal resolution. The detailed structure of the coral shows sub-annual variation that cannot be identified by traditional microdrilling techniques and, notably, also picks apart the different $\mathrm{pH}$ and carbonate parameters of the calcifying fluid which are used to precipitate different skeletal components.

Higher $\mathrm{pH}$ is maintained annually in the denser theca walls while the centre of the polyp shows the lowest $\mathrm{pH}$ and $\Omega_{\mathrm{cf}}$ and is thus the least modified from ambient seawater (although still with elevated DIC and $\left[\mathrm{HCO}_{3}{ }^{-}\right]$to twice ambient seawater concentrations). We propose that these variations in the extent of $\mathrm{pH}$ and $\Omega_{\mathrm{cf}}$ modification leads to ocean acidification having a variable effect on each structural component. Thus providing mechanistic insights into the causes of the observation ${ }^{14}$ that ocean acidification leads to less infilling of the corallite of Siderastrea siderea. Mapping the chemical and isotopic composition of coral skeletons in the fashion described here therefore provides a unique window into the processes occurring within the (sub-)micron-sized ECM and offers a new means to probe the effect of environmental change on coral calcification.

\section{Materials and methods}

Siderastrea siderea sampling. In December 2009, a Siderastrea siderea coral was cored (sample BR-06) from $\sim 5 \mathrm{~m}$ water depth on the back reef of the southern Belize portion of the Mesoamerican Barrier Reef System $\left(16.14045^{\circ} \mathrm{N}, 88.26015^{\circ} \mathrm{W}\right)$ using a 2 horse power hand-held pneumatic air drill with a custom hollow extension rod and wet diamond core bit $\left.{ }^{32,47,48}\right)$. A $5 \mathrm{~mm}$ thick slab was removed from the core and divided into $80 \mathrm{~mm}$ sections using a diamond-tipped tile saw, then individual sections were polished using a diamond plate grinder followed by silicon carbide grinding paper and mounted onto glass slides. The uppermost portion of this core was used for the present study, correlating to skeletal growth between June 2006 and January 2008 (i.e., in and around 2007).

Solution MC-ICP-MS. All geochemical analyses were performed at the University of Southampton. Solution $\delta^{11} \mathrm{~B}$ analysis was performed using a Thermo Scientific Neptune MC-ICP mass spectrometer (Thermo Fisher Scientific, Waltham, MA, USA) following previously published procedures ${ }^{49,50}$. Twenty-two samples $(0.2-0.5 \mathrm{mg})$ were micro drilled in a grid formation from the Siderastrea siderea slab, encompassing the full width of a single corallite (i.e., theca wall to theca wall) and approximately 18 months of growth, using a New Wave Research Micromill and a $500 \mu \mathrm{m}$ drill-bit. The individual holes are $500 \mu \mathrm{m}$ in depth. Samples were oxidatively cleaned in $1 \% \mathrm{H}_{2} \mathrm{O}_{2}$ at $80^{\circ} \mathrm{C}$ for $5 \mathrm{~min}$ and leached in $0.0005 \mathrm{M} \mathrm{HNO}_{3}$ prior to being dissolved in $\sim 0.15 \mathrm{M}$ $\mathrm{HNO}_{3}$. Boron was separated from the carbonate matrix by ion-exchange chromatography using $20 \mu \mathrm{l}$ Teflon columns containing Amberlite IRA743 resin, alongside a coral standard (Japanese Coralline Porites [JCp-1]). Mass bias corrections were applied by sample-standard bracketing using boron isotope standard NIST SRM951. A total procedural blank correction was applied based on analysis of the blank from the chemical separation stage, which was also used to correct the JCp-1 standard. Solution concentrations ranged from 5 to 40 ppb B and uncertainty $(2 \sigma)$ ranges from \pm 0.6 to $0.2 \%$, respectively. The data are presented in supplementary data 1 .

Laser ablation MC-ICP-MS. Laser ablation $\delta^{11} \mathrm{~B}$ isotope analysis was performed using a Thermo Scientific Neptune Plus MC-ICP mass spectrometer coupled to an Elemental Scientific Lasers (Bozeman, MT, USA) NWR193 excimer laser ablation system with a TwoVol2 ablation chamber, housed in the Geochemistry laboratory at the University of Southampton. Prior to laser ablation MC-ICP-MS the Siderastrea siderea sample was removed from the glass slide and cleaned in $20 \% \mathrm{H}_{2} \mathrm{O}_{2}$ to remove remnant organic material, then ultrasonicated for $10 \mathrm{~min}$ and rinsed three times in $18.2 \mathrm{M} \Omega \mathrm{cm}$ (ultrapure) water.

LA-MC-ICP-MS analysis broadly followed protocols published by Standish et al. ${ }^{28}$. Boron isotopes were measured on the L3 and H3 Faraday cups installed with $10^{12} \Omega$ resistors. Typical operating conditions are outlined in Table S2. Prior to data collection, the samples and standards were pre-ablated to remove any surface contamination. Data were collected in static mode using integrations of $2.194 \mathrm{~s}$ and a spot size of $140 \mu \mathrm{m}$. Analyses of reference materials integrated 100 cycles. Dynamic blank corrections were applied cycle by cycle assuming a linear relationship between the preceding and succeeding blank measurements. Instrumental mass bias was corrected by sample-standard bracketing with glass reference material NIST SRM610 and the isotope composition published by le Roux et al. ${ }^{51}$ and Standish et al. ${ }^{28}$. Matrix interference from scattered Ca ions on ${ }^{10} \mathrm{~B}$ were corrected for using the log-relationship between $\delta^{11} \mathrm{~B}$ inaccuracy and ${ }^{11} \mathrm{~B} / \mathrm{Ca} \mathrm{a}_{\text {interference }}$ for carbonate reference materials JCp-1 
(Porites sp. coral) and JCt-1 (biogenic aragonite Tridacna gigas) ${ }^{52}$, where the $\mathrm{Ca}_{\text {interference was measured at } m / z \text { of }}$ 10.10 using the L2 Faraday cup (also installed with a $10^{12} \Omega$ resistor). Data were screened and those cycles falling outside of 3 SD of the mean were removed. The data are presented in Table S3.

Internal reference material PS69/318-1 (Table S3), a fragment of a deep sea, cold water, calcitic Scleraxonian octocoral, was ablated during the analytical session $(n=3)$ giving a mean $\delta^{11} \mathrm{~B}$ value of $14.04 \pm 0.60 \%$ o $(2 \mathrm{SD})$, consistent with a solution MC-ICP-MS measurement of $13.83 \pm 0.29 \%$ o $(2 \sigma)$. Thirty adjacent $140 \mu \mathrm{m}$ wide transects (circular laser beam $140 \mu \mathrm{m}$ in diameter) of the Siderastrea siderea were ablated equating to an area of $\sim 4.2$ by $6 \mathrm{~mm}$ that encompassed approximately 1.5 corallites and corresponding to the same period of growth as the solution MC-ICP-MS analyses. The approximate depth of the ablated trenches was $\sim 5 \mu \mathrm{m}$.

Topographic impact on laser data. We highlight a difference between the $\delta^{11} \mathrm{~B}$ signature of the coral depending on the degree of porosity, and there is a possibility that this variability relates to analytical artefacts produced when ablating the irregular and/or rough surface of the coral as the laser beam tracks across the porous skeleton, e.g. due to an instrumental fractionation of the ${ }^{11} \mathrm{~B} /{ }^{10} \mathrm{~B}$ or ${ }^{11} \mathrm{~B} / \mathrm{Ca}_{\text {interference. To exclude this pos- }}$ sibility, synthetic 'pores' and trenches were created in a piece of NIST SRM612 (silicate glass reference material) to mimic the topography of the coral structure (see figure S4a). Five laser ablation transects were analysed over this area (Figure S4b) and the data processed in an identical fashion to the coral data. No discernable variation in the $\delta^{11} \mathrm{~B}$ relating to this topography was detected, therefore implying surface topography has little control on $\delta^{11} \mathrm{~B}$ measured by laser ablation. We further this analysis by investigating the Ca intensity in the ICP-MS data for our target section of Siderastrea siderea compared to B/Ca measured in the same session and the SEM image (Figure S5). We find the Ca intensity picks out the pores well (a vs. b) but this pattern is not replicated in the B/ $\mathrm{Ca}$, showing little impact from the porosity or topography. We attribute this to the normalisation to $\mathrm{Ca}$ and the lack of any significant fractionation of $\mathrm{B}$ to $\mathrm{Ca}$ due to sample topography. We also present $\mathrm{Ca}_{\text {interference }}$ (from $\mathrm{MC}$ ICPMS measurements at $10.10 \mathrm{amu}$ ) vs. $\delta^{11} \mathrm{~B}$ from four representative transects, two in the walls and two in the columella. We find no correlation of $\mathrm{Ca}_{\text {interference }}$ (which can be viewed as a proxy for the amount of sample material being ablated) with $\delta^{11} \mathrm{~B}$ in any of the transects despite the clear reduction in intensity of the Ca-interference over the higher porosity columella (top blue plots vs. bottom red plots). These findings are in good agreement with the study of Thil et al. ${ }^{53}$ that also noted surface irregularities resulting from coral skeletal porosity have little or no impact on the accuracy of laser ablation $\delta^{11} \mathrm{~B}$.

Laser ablation ICP-MS. Laser ablation trace element analysis was performed on a Thermo Scientific X-Series II Quadrupole ICP mass spectrometer coupled to an Elemental Scientific Lasers (Bozeman, MT, USA) NWR193 excimer laser ablation system with a TwoVol2 ablation chamber, housed in the Geochemistry laboratory at the University of Southampton. Typical operating conditions are outlined in Table S2. Prior to data collection, the standards were ablated to remove any surface contamination. An on-peak gas blank subtraction was performed using the mean of bracketing gas blank analyses. Raw elemental ratios were normalised against bracketing analyses of carbonate reference material JCp-1 and values ${ }^{54}$. Data were screened and those cycles falling outside of 3 SD of the mean were removed. Internal reference material PS69/318-1 was again run as a consistency standard, giving good accuracy and reproducibility (Table S3). Thirty adjacent $140 \mu \mathrm{m}$ wide transects (square laser beams of 140 by $50 \mu \mathrm{m}$ area) of the Siderastrea siderea were ablated covering the same area which had previously been ablated for $\delta^{11} \mathrm{~B}$ isotope analysis. Uncertainty, which ranges from 16 to $26 \%$ on all ratios $(2 \sigma)$, was determined from whichever was the higher out of: the 2 SD of repeat measurements of the deep sea coral reference material PS69/318-1 or the mode (to two significant figures) of a 15-point running mean of the entire element/Ca dataset, which captures reproducibility in the gridded data but without being unduly impacted by rapid environmental changes. Both of these are considered to be conservative approaches.

Isotopic and elemental mapping. Despite the isotopic and trace element data being collected using the same laser conditions and scan speed, the different integration times for the different mass spectrometric techniques resulted in the $\delta^{11} \mathrm{~B}$ and trace element line profiles having a different initial resolution (272 vs. 3311 data points per line). Each laser line for $\delta^{11} \mathrm{~B}$ and trace elements was firstly subjected to a 3SD rejection to remove any outliers and then a simple moving average was used to smooth the data. The width of the moving average window was 5 points for the $\delta^{11} \mathrm{~B}$ data and 15 points for the trace element data. The 30 separate smoothed laser lines were mapped onto an equal spaced grid using their X and $\mathrm{Y}$ spatial coordinates from Elemental Scientific Lasers (Bozeman, MT, USA) NWR193 excimer laser ablation system. The dimensions of the grid were governed by the resolution of the $\delta^{11} \mathrm{~B}$ data and was constructed using the Raster package ${ }^{55}$ in $\mathrm{R}^{56}$ utilising the "filledcontour" function. The $\mathrm{X}-\mathrm{Y}$ resolution of the images produced was $147 \times 21$ microns per pixel.

Mapping of the carbonate system. Reference points were used to precisely align the $\delta^{11} \mathrm{~B}$ and $\mathrm{B} / \mathrm{Ca}$ grids, with the former resampled onto the grid of the latter. The combined data from $\delta^{11} \mathrm{~B}$ (converted to $\mathrm{pH}$ as in Eq. 1) and B/Ca (Eq. 2) was then used to calculate the carbonate system (largely following DeCarlo et al. ${ }^{12}$ and Holcomb et $\mathrm{al}^{57}$ ). In these calculations $\mathrm{pK}_{\mathrm{B}}$ is assumed constant, i.e. we are not accounting for temperature. This assumption however, will only have small impact on these data as the seasonal temperature change in this region is $3{ }^{\circ} \mathrm{C}=0.3 \%$ o change in $\delta^{11} \mathrm{~B}$. The carbonate data were calculated using the values from the relevant raster grid and imaged using the Raster function in $\mathrm{R}^{55,56}$.

$$
p H_{c f}=p K_{B}-\log \left(-\frac{\delta^{11} B_{S W}-\delta^{11} B_{\mathrm{CaCO}_{3}}}{\delta^{11} B_{S W}-\alpha_{B} \cdot \delta^{11} B_{\mathrm{CaCO}_{3}}-1000 \cdot\left(\alpha_{B}-1\right)}\right)
$$


where $\delta^{11} \mathrm{~B}_{\mathrm{sW}}=39.61 \% \mathrm{o}^{58}, \mathrm{pK}_{\mathrm{B}}=8.6$ and the isotopic fractionation factor $\left(\alpha_{\mathrm{B}}\right)=1.0272$ Klochko et al. ${ }^{59}$.

To calculate $\left[\mathrm{CO}_{3}{ }^{2-}\right]$ (in $\left.\mu \mathrm{mol} / \mathrm{l}\right)$ we used a simplified relationship between $\left[\mathrm{CO}_{3}{ }^{2-}\right]$, borate ion $\left(\left[\mathrm{B}(\mathrm{OH})_{4}{ }^{-}\right]_{\mathrm{cf}}\right.$ in $\mu \mathrm{mol} / \mathrm{l})$ and $\mathrm{B} / \mathrm{Ca}(\mu \mathrm{mol} / \mathrm{mol})$ fitted to the data of Holcomb et $\mathrm{al}^{57}$ :

$$
\left[\mathrm{CO}_{3}^{2-}\right]_{c f}=0.00297 \times\left(\frac{\left[\mathrm{B}(\mathrm{OH})_{4}^{-}\right]_{c f}}{\mathrm{~B} / \mathrm{Ca}} \times 10^{6}\right)
$$

where $\left[\mathrm{B}(\mathrm{OH})_{4}{ }^{-}\right]_{\mathrm{cf}}$ is calculated, following Dickson ${ }^{60}$ and using the seawater boron concentration from Lee et al. ${ }^{61}$, from:

$$
\left[\mathrm{B}(\mathrm{OH})_{4}^{-}\right]_{c f}=\frac{432.6}{1+[\mathrm{H}]^{+} / K_{B}}
$$

Seawater [Ca] is kept constant at $10 \mathrm{mmol} / \mathrm{kg}$ and other carbonate system parameters were calculated following the equations in ${ }^{12,62}$.

Imaging comparison to porosity. To compare the reconstructed carbonate system variables to porosity, we convert all the maps and the SEM image to 8-bit (0-255 value) greyscale in Image ${ }^{63}$. In the SEM image grey scale value is primarily related to the porosity and therefore is a proxy for skeletal density (or amount of carbonate in a particular region). For all the carbonate variables, the colour schemes used indicate that lighter colours are associated with higher values (Figure S2). These greyscale values are averaged in 100 pixel-wide vertical bins to give an average for the various skeletal components (which run approximately vertically in our sectioned coral). We then cross plot the 'porosity' proxy values against each of the carbonate parameters both as raw data and with any long-term trend (which may be indicative of a long-term environmental shift) removed by subtraction (Figure S3). The cross-correlation values for each parameter are shown in Table 1, and the cross plots for DIC and $\left[\mathrm{HCO}_{3}{ }^{-}\right]$are shown in Figure S3.

Received: 18 September 2020; Accepted: 30 November 2020

Published online: 12 January 2021

\section{References}

1. Cesar, H. J. S., Burke, L. \& Pet-Soede, L. The Economics of Worldwide Coral Reef Degradation. 23 (Cesar Environmental Economics Consulting: The Netherlands). https://www.icran.org/pdf/cesardegradationreport.pdf (2003).

2. Tambutté, E. et al. Observations of the tissue-skeleton interface in the scleractinian coral Stylophora pistillata. Coral Reefs 26, 517-529 (2007).

3. Mollica, N. R. et al. Ocean acidification affects coral growth by reducing skeletal density. Proc. Natl. Acad. Sci. 115, 1754-1759 (2018).

4. Mass, T. et al. Cloning and characterization of four novel coral acid-rich proteins that precipitate carbonates in vitro. Curr. Biol. 23, 1126-1131. https://doi.org/10.1016/j.cub.2013.05.007 (2013).

5. Guo, W. Seawater temperature and buffering capacity modulate coral calcifying pH. Sci. Rep. 9, 1-13 (2019).

6. McCulloch, M. et al. Resilience of cold-water scleractinian corals to ocean acidification: boron isotopic systematics of $\mathrm{pH}$ and saturation state up-regulation. Geochim. Cosmochim. Acta 87, 21-34 (2012).

7. Guo, W. et al. Ocean acidification has impacted coral growth on the great barrier reef. Geophys. Res. Lett. https://doi. org/10.1029/2019gl086761 (2020).

8. Sevilgen, D. S. et al. Full in vivo characterization of carbonate chemistry at the site of calcification in corals. Sci. Adv. https://doi. org/10.1126/sciadv.aau7447 (2019).

9. Venn, A., Tambutté, E., Holcomb, M., Allemand, D. \& Tambutté, S. Live tissue imaging shows reef corals elevate pH under their calcifying tissue relative to seawater. PLoS ONE 6, e20013 (2011).

10. Cai, W.-J. et al. Microelectrode characterization of coral daytime interior $\mathrm{pH}$ and carbonate chemistry. Nat. Commun. 7, 1-8 (2016).

11. Holcomb, M. et al. Coral calcifying fluid pH dictates response to ocean acidification. Sci. Rep. 4, 5207. https://doi.org/10.1038/ srep05207 (2014).

12. DeCarlo, T. M., Holcomb, M. \& McCulloch, M. T. Reviews and syntheses: revisiting the boron systematics of aragonite and their application to coral calcification. Biogeosciences 15, 2819-2834. https://doi.org/10.5194/bg-15-2819-2018 (2018).

13. McCulloch, M. T., D'Olivo, J. P., Falter, J., Holcomb, M. \& Trotter, J. A. Coral calcification in a changing world and the interactive dynamics of pH and DIC upregulation. Nat. Commun. 8, 15686. https://doi.org/10.1038/ncomms15686 (2017).

14. Horvath, K. M. et al. Next-century ocean acidification and warming both reduce calcification rate, but only acidification alters skeletal morphology of reef-building coral Siderastrea siderea. Sci. Rep. 6, 29613. https://doi.org/10.1038/srep29613 (2016).

15. Tambutté, E. et al. Morphological plasticity of the coral skeleton under $\mathrm{CO}_{2}$-driven seawater acidification. Nat. Commun. 6, 7368. https://doi.org/10.1038/ncomms8368 (2015).

16. Stewart, J. A., Anagnostou, E. \& Foster, G. L. An improved boron isotope $\mathrm{pH}$ proxy calibration for the deep-sea coral Desmophyllum dianthus through sub-sampling of fibrous aragonite. Chem. Geol. 447, 148-160. https://doi.org/10.1016/j.chemgeo.2016.10.029 (2016).

17. Allison, N., Finch, A. A. \& EIMF. $\delta^{11} \mathrm{~B}, \mathrm{Sr}, \mathrm{Mg}$ and B in a modern Porites coral: the relationship between calcification site $\mathrm{pH}$ and skeletal chemistry. Geochim. Cosmochim. Acta 74, 1790-1800 (2010).

18. Rollion-Bard, C. \& Blamart, D. SIMS method and examples of applications in coral biomineralization. In Biomineralization Sourcebook: Characterization of Biominerals and Biomimetic Materials (eds DiMasi, E. \& Gower, L. B.) 249-261 (CRC Press, Boca Raton, 2014).

19. Trotter, J. et al. Quantifying the $\mathrm{pH}$ 'vital effect' in the temperate zooxanthellate coral Cladocora caespitosa: validation of the boron seawater pH proxy. Earth Planet. Sci. Lett. 303, 163-173. https://doi.org/10.1016/j.epsl.2011.01.030 (2011).

20. Krief, S. et al. Physiological and isotopic responses of scleractinian corals to ocean acidification. Geochim. Cosmochim. Acta 74, 4988-5001 (2010). 
21. Hönisch, B. et al. Assessing scleractinian corals as recorders for paleo-pH: empirical calibration and vital effects. Geochim. Cosmochim. Acta 68, 3675-3685. https://doi.org/10.1016/j.gca.2004.03.002 (2004).

22. Tanaka, K. et al. Response of Acropora digitifera to ocean acidification: constraints from $\delta^{11} \mathrm{~B}, \mathrm{Sr}, \mathrm{Mg}$, and $\mathrm{Ba}$ compositions of aragonitic skeletons cultured under variable seawater pH. Coral Reefs 34, 1139-1149 (2015).

23. Reynaud, S., Hemming, N. G., Juillet-Leclerc, A. \& Gattuso, J.-P. Effect of $\mathrm{pCO}_{2}$ and temperature on the boron isotopic composition of the zooxanthellate coral Acropora sp. Coral Reefs 23, 539-546 (2004).

24. Anagnostou, E., Huang, K.-F., You, C.-F., Sikes, E. \& Sherrell, R. Evaluation of boron isotope ratio as a pH proxy in the deep sea coral Desmophyllum dianthus: evidence of physiological pH adjustment. Earth Planet. Sci. Lett. 349, 251-260 (2012).

25. Jurikova, H. et al. Boron isotope composition of the cold-water coral Lophelia pertusa along the Norwegian margin: zooming into a potential pH-proxy by combining bulk and high-resolution approaches. Chem. Geol. 513, 143-152. https://doi.org/10.1016/j. chemgeo.2019.01.005 (2019).

26. Kasemann, S. A., Schmidt, D. N., Bijma, J. \& Foster, G. L. In situ boron isotope analysis in marine carbonates and its application for foraminifera and palaeo-pH. Chem. Geol. https://doi.org/10.1016/j.chemgeo.2008.12.015 (2009).

27. Rollion-Bard, C., Chaussidon, M. \& France-Lanord, C. pH control on oxygen isotopic composition of symbiotic corals. Earth Planet. Sci. Lett. 215, 275-288. https://doi.org/10.1016/S0012-821X(03)00391-1 (2003).

28. Standish, C. D. et al. The effect of matrix interferences on in situ boron isotope analysis by laser ablation multi-collector inductively coupled plasma mass spectrometry. Rapid Commun. Mass Spectrom. 33, 959-968 (2019).

29. Sadekov, A. et al. Accurate and precise microscale measurements of boron isotope ratios in calcium carbonates using laser ablation multicollector-ICPMS. J. Anal. At. Spectrom. 34, 550-560 (2019).

30. Fietzke, J. et al. Boron isotope ratio determination in carbonates via LA-MC-ICP-MS using soda-lime glass standards as reference material. J. Anal. At. Spectrom. 25, 1953-1957 (2010).

31. Oppelt, A., López, M. \& Rocha, C. Biogeochemical analysis of the calcification patterns of cold-water corals Madrepora oculata and Lophelia pertusa along contact surfaces with calcified tubes of the symbiotic polychaete Eunice norvegica: evaluation of a 'mucus' calcification hypothesis. Deep Sea Res. I Oceanogr. Res. Pap. 127, 90-104. https://doi.org/10.1016/j.dsr.2017.08.006 (2017).

32. Fowell, S. et al. Historical trends in $\mathrm{pH}$ and carbonate biogeochemistry on the Belize Mesoamerican Barrier Reef System. Geophys. Res. Lett. 45, 3228-3237 (2018).

33. Runcorn, S. K. Corals as paleontological clocks. Sci. Am. 215, 26-33 (1966).

34. DeCarlo, T. M. \& Cohen, A. L. Dissepiments, density bands and signatures of thermal stress in Porites skeletons. Coral Reefs 36, 749-761. https://doi.org/10.1007/s00338-017-1566-9 (2017).

35. Barnes, D. \& Lough, J. On the nature and causes of density banding in massive coral skeletons. J. Exp. Mar. Biol. Ecol. 167, 91-108 (1993).

36. DeCarlo, T. M. et al. Coral Sr-U thermometry. Paleoceanography 31, 626-638 (2016).

37. Gagnon, A. C., Adkins, J. F., Fernandez, D. P. \& Robinson, L. F. Sr/Ca and Mg/Ca vital effects correlated with skeletal architecture in a scleractinian deep-sea coral and the role of Rayleigh fractionation. Earth Planet. Sci. Lett. 261, 280-295. https://doi.org/10.1016/j. epsl.2007.07.013 (2007).

38. Blamart, D. et al. Correlation of boron isotopic composition with ultrastructure in the deep-sea coral Lophelia pertusa: implications for biomineralization and paleo-pH. Geochem. Geophys. Geosyst. https://doi.org/10.1029/2007GC001686 (2007).

39. Jokiel, P. L. Coral reef calcification: carbonate, bicarbonate and proton flux under conditions of increasing ocean acidification. Proc. Biol. Sci. 280, 20130031-20130031. https://doi.org/10.1098/rspb.2013.0031 (2013).

40. Galli, G. \& Solidoro, C. ATP supply may contribute to light-enhanced calcification in corals more than abiotic mechanisms. Front. Mar. Sci. https://doi.org/10.3389/fmars.2018.00068 (2018).

41. Barott, K. L., Venn, A. A., Perez, S. O., Tambutté, S. \& Tresguerres, M. Coral host cells acidify symbiotic algal microenvironment to promote photosynthesis. Proc. Natl. Acad. Sci. 112, 607-612. https://doi.org/10.1073/pnas.1413483112 (2015).

42. Bernardet, C., Tambutté, E., Techer, N., Tambutté, S. \& Venn, A. Ion transporter gene expression is linked to the thermal sensitivity of calcification in the reef coral Stylophora pistillata. Sci. Rep. 9, 1-13 (2019).

43. Le Goff, C. et al. In vivo $\mathrm{pH}$ measurement at the site of calcification in an octocoral. Sci. Rep. 7, 11210. https://doi.org/10.1038/ s41598-017-10348-4 (2017).

44. Zoccola, D. et al. Bicarbonate transporters in corals point towards a key step in the evolution of cnidarian calcification. Sci. Rep. 5, 9983. https://doi.org/10.1038/srep09983 (2015).

45. Furla, P., Galgani, I., Durand, I. \& Allemand, D. Sources and mechanisms of inorganic carbon transport for coral calcification and photosynthesis. J. Exp. Biol. 203, 3445-3457 (2000).

46. DeLong, K. L., Maupin, C. R., Flannery, J. A., Quinn, T. M. \& Shen, C.-C. Refining temperature reconstructions with the Atlantic coral Siderastrea siderea. Palaeogeogr. Palaeoclimatol. Palaeoecol. 462, 1-15. https://doi.org/10.1016/j.palaeo.2016.08.028 (2016).

47. Castillo, K. D., Ries, J. B. \& Weiss, J. M. Declining coral skeletal extension for forereef colonies of Siderastrea siderea on the Mesoamerican Barrier Reef System Southern Belize. PLoS ONE 6, e14615 (2011).

48. Castillo, K. D., Ries, J. B., Weiss, J. M. \& Lima, F. P. Decline of forereef corals in response to recent warming linked to history of thermal exposure. Nat. Clim. Change 2, 756-760. https://doi.org/10.1038/nclimate1577 (2012).

49. Foster, G. L. Seawater $\mathrm{pH}, \mathrm{pCO}_{2}$ and $\mathrm{CO}_{3}{ }^{2-}$ variations in the Caribbean Sea over the last $130 \mathrm{kyr}$ : a boron isotope and $\mathrm{B} / \mathrm{Ca}$ study of planktic forminifera. Earth Planet. Sci. Lett. 271, 254-266. https://doi.org/10.1016/j.epsl.2008.04.015 (2008).

50. Foster, G. L. et al. Interlaboratory comparison of boron isotope analyses of boric acid, seawater and marine $\mathrm{CaCO}_{3}$ by $\mathrm{MC}$-ICPMS and NTIMS. Chem. Geol. 358, 1-14. https://doi.org/10.1016/j.chemgeo.2013.08.027 (2013).

51. le Roux P. J. et al. In situ, multiplemultiplier, laser ablation ICP-MS measurement of boron isotopic composition $(\delta 11 \mathrm{~B})$ at the nanogram level. Chem. Geol. 203(1-2), 123-138. https://doi.org/10.1016/j.chemgeo.2003.09.006 (2004).

52. Inoue, M., Nohara, M., Okai, T., Suzuki, A. \& Kawahata, H. Concentrations of trace elements in carbonate reference materials coral JCp-1 and Giant Clam JCt-1 by inductively coupled plasma-mass spectrometry. Geostand. Geoanal. Res. 28, 411-416. https ://doi.org/10.1111/j.1751-908X.2004.tb00759.x (2004).

53. Thil, F. et al. Development of laser ablation multi-collector inductively coupled plasma mass spectrometry for boron isotopic measurement in marine biocarbonates: new improvements and application to a modern Porites coral. Rapid Commun. Mass Spectrom. 30, 359-371 (2016).

54. Hathorne, E. C. et al. Interlaboratory study for coral Sr/Ca and other element/Ca ratio measurements. Geochem. Geophys. Geosyst. 14, 3730-3750. https://doi.org/10.1002/ggge.20230 (2013).

55. Hijmans, R. \& Van Etten, J. Geographic analysis and modeling with raster data. R Package Version 2, 1-25 (2012).

56. R: A language and environment for statistical computing (R Foundation for Statistical Computing, Vienna, Austria, 2010).

57. Foster, G. L., von Strandmann, P. \& Rae, J. W. B. Boron and magnesium isotopic composition of seawater. Geochem. Geophys. Geosyst. https://doi.org/10.1029/2010gc003201 (2010).

58. Klochko, K., Kaufman, A. J., Yao, W. S., Byrne, R. H. \& Tossell, J. A. Experimental measurement of boron isotope fractionation in seawater. Earth Planet. Sci. Lett. https://doi.org/10.1016/j.epsl.2006.05.034 (2006).

59. Holcomb, M., DeCarlo, T., Gaetani, G. \& McCulloch, M. Factors affecting B/Ca ratios in synthetic aragonite. Chem. Geol. 437, 67-76 (2016).

60. Dickson, A. G. Thermodynamics of the dissociation of boric acid in synthetic seawater from 273.15 to 318.15 K. Deep Sea Res. Oceanogr. Res. Pap. 37, 755-766. https://doi.org/10.1016/0198-0149(90)90004-F (1990). 
61. Lee, K. et al. The universal ratio of boron to chlorinity for the North Pacific and North Atlantic oceans. Geochim. Cosmochim. Acta 74, 1801-1811 (2010).

62. Zeebe, R. E. \& Wolf-Gladrow, D. A. $\mathrm{CO}_{2}$ in Seawater: Equilibrium, Kinetics, Isotopes in Seawater: Equilibrium, Kinetics, Isotopes Vol. 65 (Elsevier, Amsterdam, 2001).

63. Schneider, C. A., Rasband, W. S. \& Eliceiri, K. W. NIH Image to ImageJ: 25 years of image analysis. Nat. Methods 9, 671-675. https ://doi.org/10.1038/nmeth.2089 (2012).

\section{Acknowledgements}

Kathryn Shaw, Megan Wilding and Richard Pearce are acknowledged for their help with SEM and optical imaging. Matt Cooper, Agnes Michalik and the B-team are thanked for their analytical support, and Dan Doran and Matt Beverley-Smith are gratefully acknowledged for their help sectioning coral slabs. This work was funded by the Leverhulme Trust that supported TBC and CDS, and ERC Advanced Grant Micons2Reefs (\#884650), both awarded to GLF.

\section{Author contributions}

T.B.C., C.D.S. and J.A.M. collected the primary data, T.B.C., C.D.S. and G.L.F. conceived the study. Statistical analysis performed by T.B.C. and G.L.F. C.D. and K.D.C. helped to analyse the data. All authors contributed to the final manuscript.

\section{Competing interests}

The authors declare no competing interests.

\section{Additional information}

Supplementary Information The online version contains supplementary material available at https://doi. org/10.1038/s41598-020-78778-1.

Correspondence and requests for materials should be addressed to T.B.C.

Reprints and permissions information is available at www.nature.com/reprints.

Publisher's note Springer Nature remains neutral with regard to jurisdictional claims in published maps and institutional affiliations.

(c) (i) Open Access This article is licensed under a Creative Commons Attribution 4.0 International

License, which permits use, sharing, adaptation, distribution and reproduction in any medium or format, as long as you give appropriate credit to the original author(s) and the source, provide a link to the Creative Commons licence, and indicate if changes were made. The images or other third party material in this article are included in the article's Creative Commons licence, unless indicated otherwise in a credit line to the material. If material is not included in the article's Creative Commons licence and your intended use is not permitted by statutory regulation or exceeds the permitted use, you will need to obtain permission directly from the copyright holder. To view a copy of this licence, visit http://creativecommons.org/licenses/by/4.0/.

(C) The Author(s) 2021 